Balland, E. 364

Boyle, J. 412

Cardinali, D.P. 317, 382

Chen, W. 364

Chiu, W.-L. 412

Cowley, M.A. 364

Diéguez, C. 398

Faulkner, L.D. 330

Fernø, J. 398

Gagliardino, J.J. 317, 347

González-García, I. 398
Hardeland, R 382

Henry, B.A. 319

Hill, J.W. 330

López, M. 398

Moran, L.J. 412

Nogueiras, R. 398

Pagano, E.S. 347

Spinedi, E. 317, 347

Teede, H. 412

Vincent, A. 412

\title{
Subject Index Vol. 104, No. 4, 2017
}

Adipose tissue dysfunction 347

- - mass expansion 347

Aging 382

Appetite-regulating peptides 319

Cardiometabolic risks 412

Central/peripheral clocks 347

Chronobiology 347

Chronotherapeutic approach 347

Clock genes 347

Diabetes 382

Feeding time 347

Glucose metabolism 364

- regulation 347

Hepatic glucose production 364

Hyperandrogenism 412

Hyperinsulinemia 364

Hypothalamic lipids 398

Hypothalamus 319
Inflammation 382

Insulin receptor 364

- resistance 364, 412

- signaling 382

Melanocortin system 330

Melatonin 382

Metabolic disease 330

- syndrome 382

Metabolism 398

Nutrients 347

Obesity $319,330,382,412$

- pathogenesis 347

- prevention/treatment 347

Polycystic ovary syndrome 412

Thermogenesis 319

Whole body energy balance 398 